Bond University

Research Repository

\title{
Critique of the five-factor model of personality
}

\section{Boyle, Gregory J.}

\section{Published in:}

The SAGE Handbook of Personality Theory and Assessment: Volume 1 - Personality Theories and Models

DOI:

10.4135/9781849200462.n14

Licence:

Other

Link to output in Bond University research repository.

Recommended citation(APA):

Boyle, G. J. (2008). Critique of the five-factor model of personality. In G. J. Boyle, G. Matthews, \& D. H.

Saklofske (Eds.), The SAGE Handbook of Personality Theory and Assessment: Volume 1 - Personality Theories and Models (pp. 295-312). SAGE Publications Ltd. https://doi.org/10.4135/9781849200462.n14

\footnotetext{
General rights

Copyright and moral rights for the publications made accessible in the public portal are retained by the authors and/or other copyright owners and it is a condition of accessing publications that users recognise and abide by the legal requirements associated with these rights.
}

For more information, or if you believe that this document breaches copyright, please contact the Bond University research repository coordinator. 


\section{Bond University}

\section{ePublications@bond}

Humanities \& Social Sciences papers

Faculty of Humanities and Social Sciences

$1-1-2008$

\section{Critique of the five-factor model of personality}

Gregory J. Boyle

Bond University, Gregory_Boyle@bond.edu.au

Follow this and additional works at: http://epublications.bond.edu.au/hss_pubs

Part of the Personality and Social Contexts Commons

\section{Recommended Citation}

Boyle, Gregory J., "Critique of the five-factor model of personality" (2008). Humanities \& Social Sciences papers. Paper 297. http://epublications.bond.edu.au/hss_pubs/297

This Book Chapter is brought to you by the Faculty of Humanities and Social Sciences at ePublications@bond. It has been accepted for inclusion in Humanities \& Social Sciences papers by an authorized administrator of ePublications@bond. For more information, please contact Bond University's Repository Coordinator. 
Word Count: 9,303

Critique of Five Factor Model of Personality

Gregory J. Boyle

Department of Psychology, Bond University

and

Department of Psychiatry, University of Queensland 


\section{Introduction: Lexical Coverage of the Personality Trait Sphere}

Assuming that most aspects of human personality structure are represented in the trait lexicon (i.e., that the personality sphere is encompassed by trait-descriptive words--see Ashton et al., 2004; Saucier \& Goldberg, 2001), Allport and Odbert’s (1936) list of more than 4000 English trait descriptors was reduced down to some 35+ clusters of trait synonyms (e.g., Cattell, 1986). Raymond B. Cattell (who, along with Freud, Piaget, and Eysenck, was listed among the 10 most highly-cited psychologists of the $20^{\text {th }}$ century--Haggbloom et al., 2002, p. 142), attempted a comprehensive sampling of the trait lexicon, on the assumption that the most important attributes of human personality are encoded in the English language (cf. John, 1990; Peabody \& DeRaad, 2002). It was Cattell's early pioneering work that served as the starting point for the subsequent lexically-based development of the popular Five Factor Model (FFM) of personality structure which includes dimensions (traits) labelled Neuroticism (N), Extraversion (E), Openness to Experience--Intellectance (O), Agreeableness (A), and Conscientiousness (C). The FFM dimensions were derived from various factor analytic studies of self-report and peer reports of adjectival (e.g., Goldberg's, 1992, Big Five) and questionnaire personality-related data (e.g., Costa \& McCrae’s, 1992, FFM). However, it is important to note that some significant aspects of this factor-analytic work leading to the current FFM have been methodologically flawed (Boyle et al., 1995; Boyle \& Saklofske, 2004). Although the Big Five (e.g., Goldberg, 1993) and the FFM (e.g., Costa \& McCrae, 1992) dimensions technically are considered to be conceptuallydistinct constructs, in this chapter, for ease of presentation, these terms are used interchangeably. 
Contemporary personality research generally adopts an interactionist model, whereby traits and situationally-derived states interact in influencing behavioural outcomes. However, some support for the causal nature of the Big Five has been forthcoming. For example, it has been argued that individuals vary on each of these five trait dimensions in line with the normal curve distribution and that the factors are at least partially genetically pre-determined (Jang et al., 2002; Loehlin et al., 1998). Furthermore, research within the framework of evolutionary psychology has also provided some evidence that these five personality dimensions may have influenced social adaptation and natural selection (Buss, 1996), although probably similar claims could be made about any putative set of personality trait dimensions.

While the two largest factors (Anxiety/Neuroticism and Extraversion) appear to have been universally accepted (e.g., in the pioneering factor-analytic work of R. B. Cattell, H. J. Eysenck, J. P. Guilford, and A. L. Comrey), the present critique suggests, nevertheless, that the FFM provides a less than optimal account of human personality structure. Saucier and Goldberg (2001) reported many difficulties with the proposed Big Five personality dimensions, and indeed, Saucier (2002, p. 1) concluded that, "it is not yet clear that this is the 'optimal' model. An optimal model will be replicable across methods, cross-culturally generalizable, comprehensive, and high in utility” (cf. De Raad \& Perugini, 2002). Furthermore, in analyses of adjectival data, Paunonan and Jackson (2000) provided hard evidence that many personality traits lie beyond the putative Big Five dimensions (such as Conservativeness, Honesty, Deceptiveness, Conceit, Masculinity-Femininity, Thriftiness, Humorousness, Sensuality, and Religiosity). Moreover, as indicated above, in a critique of the empirical factor-analytic work leading to delineation of the FFM, Boyle et al. (1995) 
pointed to some questionable methodological decisions, including Costa and McCrae’s (1992) use of procrustean factor-analytic techniques to ensure that factors supporting their Big Five model would be extracted (Block, 1995; Boyle, 1997).

In addition, the FFM provides a rather static account of personality (Terracciano et al., 2006). According to McCrae and Costa (1999, p. 145), personality traits develop throughout the childhood years and from around 30 years of age onwards remain relatively stable in otherwise healthy individuals. Soldz and Vaillant (1999) reported some significant test-retest correlations for some of the Big Five dimensions (Neuroticism, Extraversion, and Openness), but failed to find significant correlations for other traits (Agreeableness and Conscientiousness) across the 45-year test-retest period. The significant test-retest correlations accounted for only a small proportion of the variance, suggesting that the Big Five personality traits are subject to considerable change across the adult years. Actually, the great minds of personality psychology (Cattell, Allport, Murray) all thought that personality dispositions changed, leading to the inference that the FFM model may be an anachronism of the present generation (Roberts, 2006). Indeed, there is now mounting empirical evidence that ongoing changes to personality structure occur across the whole lifespan (e.g., see Cattell et al., 2002; Fraley \& Roberts, 2005; Roberts et al., 2006a,b). In the light of this empirical evidence, McCrae and Terracciano (2005) have acknowledged that there are discernible increases in Agreeableness and Conscientiousness over the adult years, along with decreases in Extraversion, Neuroticism, and Openness to Experience (cf. Srivastava et al., 2003). In a large meta-analytic study of nearly 100 longitudinal studies into the stability of personality traits (Roberts et al., 2006a,b), significant changes in mean trait levels were found right across the lifespan, including 
even among the elderly. While many such changes were linear, some changes were curvilinear (e.g., it was found that Openness to Experience increased during adolescence but decreased in old age). Evidently, the modification of personality traits (personality learning) continues throughout the adult years confirming Cattell's contentions regarding structured-personality-learning theory (e.g., Cattell, 1983, 1996; Cattell et al., 2002). Clearly, the "set in plaster" hypothesis put forward by McCrae and Costa (1999) that personality learning virtually ceases at around 30 years of age, is not supported by the mounting empirical research evidence to the contrary.

As an hierarchical model, the FFM potentially provides a useful structure for understanding the organization of personality constructs, at least within the normal trait sphere. While some evidence supports the cross-cultural replicability of the Big Five (e.g., Egger et al., 2003), the fact that each of the broad dimensions has multiple underlying environmental and genetic determinants, raises concerns about construct validity (Jang et al., 2002, p. 99). For example, as Saucier (2002, p. 1) pointed out, empirical evidence shows that the Big Five dimensions are not always orthogonal in marker sets. Furthermore, Toomela (2003, p. 723) reported that a coherent FFM personality structure emerged only among samples of individuals who had received extensive formal education, thereby raising doubts as to the genetic determination of the postulated Big Five personality dimensions (cf. Roberts et al., 2006a,b). Despite the popularity of the FFM in recent years, its construct validity has been queried (e.g., see Block, 1995; Boyle, 1997, Boyle \& Smári, 1997, 1998; Boyle et al., 1995; Cattell, 1995; Eysenck, 1991, 1992, 1994). 
The present critique further reviews the empirical research evidence (see metaanalytic review by Saulsman et al., 2004) pertaining to the putative Big Five dimensions, including examination of work in applied areas such as clinical psychological assessment and occupational selection. Issues considered include (1) the FFM in relation to other trait taxonomies; (2) the adequacy of the trait lexicon in covering the total personality domain (including normal, abnormal, and dynamic trait dimensions); (3) adequacy of the factor-analytic methodology used in the derivation of the FFM structure, as measured by the NEO-PI-R and 16PF instruments; and finally, (4) utility of the FFM in various applied areas of psychological practice (including clinical and occupational psychology).

\section{The FFM versus Other Personality Trait Models}

Even though the FFM is based on an atheoretical taxonomy of trait descriptors, it has, nevertheless, received wide general acceptance (O’Connor, 2002). As already stated above, two factors (Extraversion and Neuroticism) appear to be universally accepted and they appear in all major contemporary models of broad personality traits. However, interpretation of the remaining three Big Five dimensions (Openness to Experience--Intellectance, Agreeableness, and Conscientiousness) continues to remain controversial. Indeed, various alternative dimensions have been put forward (e.g., see Block, 1995, 2001; Boyle \& Smári, 1997, 1998; Boyle et al., 1995; Cattell, 1995; Eysenck, 1991, 1992, 1993; Hough, 1992; McAdams, 1992; McKenzie, 1998; Zuckerman, 2002; Zuckerman et al., 1993). Taken together, these findings raise concerns about the adequacy of the proposed FFM. 
Measures of the three broad personality dimensions Extraversion, Neuroticism, and Psychoticism (which have psychobiological underpinnings) were incorporated into the Eysenck Personality Questionnaire and its revised version (EPQ-R). Eysenck 1991, 1992) asserted that Costa and McCrae’s reported criteria for accepting the FFM were insufficient for determining the dimensions of personality structure. He argued that Agreeableness and Conscientiousness are primary facets/traits (of the EPQ-R Psychoticism factor). In any event, it is likely that the three Eysenckian personality factors (E, N, P) and the Big Five dimensions reflect different levels of description of hierarchically-arranged personality traits (Boyle, 1989).

Any detailed consideration of the FFM requires an understanding of the historical development of the model and associated psychometric measures. Several Big Five self-report and adjectival rating scales have been devised (see Matthews et al., 2003), including the Big-Five Inventory (Benet-Martínez \& John, 1998; John \& Srivastava, 1999); Goldberg’s 100-trait Adjective Rating Checklist (Goldberg, 1992), and short-form (Saucier, 1994); as well as the Big Five Questionnaire and the Big Five Observer (Caprara et al., 1994). More recently, Gosling et al. (2003) constructed a brief 10-item measure, while Paunonen (2003; Paunonen et al., 2001) constructed the Five-Factor Nonverbal Personality Questionnaire. Arrival of the NEO Personality Inventory and the revised NEO-PI-R (Costa \& McCrae, 1992; McCrae \& Costa, 2004) has greatly bolstered FFM studies. In addition, a short 60item form of the NEO-PI-R (the Five Factor Inventory or NEO-FFI) has been administered in many studies involving pre-adolescents (e.g., Markey et al., 2003; Scholte \& De Bruyn, 2004). 
Of these FFM instruments, the NEO-PI-R appears to have received the most attention over recent years. In addition to measuring the putative Big Five personality dimensions, the NEO-PI-R also comprises 30 facet scales which appear to vary in levels of heritability (Jang et al., 2002), highlighting the importance of primary factors (or facet dimensions), in addition to second-stratum dimensions. Indeed, Mershon and Gorsuch (1988) demonstrated that higher-stratum models such as the FFM, account for a considerably lower proportion of the predictive validity than do first-stratum (primary) factors such as those measured in the 16PF. Thus, there is little doubt that primary factors (including the NEO-PI-R facet subscales) measure a significantly greater proportion of the personality trait variance over and above that represented in their respective higher-stratum domains (Quirk et al., 2003).

The NEO PI-R has been utilized considerably in empirical research into the relationship between broad personality dimensions and various external criteria (e.g., see Angleitner \& Ostendorf, 1994; Barbaranelli \& Caprara, 2000; Deary, 1996; Deary \& Mathews, 1993; Jang et al., 2002; John, 1990; Marusic et al., 1996; McKenzie, 1998; Miller et al., 2004; Piedmont \& Chae, 1997; Trull et al., 1998). In addition, reservations have been raised about the susceptibility to motivational response distortion of the NEO-PI-R and the shortened NEO-FFI instruments. While there have been attempts to devise validity scales (e.g., Schinka et al., 1997; Scandell, 2000), their utility remains to be determined. Furthermore, Egan et al. (2000) in their study using the NEO-FFI reported that Neuroticism, Agreeableness, and Conscientiousness were found to exhibit greater reliability than the Openness and Extraversion dimensions. 
Even though some investigators (e.g., Angleitner \& Ostendorf, 1994) have sought evidence of concurrent validity evidence, the empirical data suggest that the FFM accounts for less than $60 \%$ of the known personality trait variance (see Boyle et al., 1995). Evidently, the FFM as measured in the NEO-PI-R instrument provides only a partial description of the actual complexity of human personality structure (cf. Aluja et al., 2004; Shafer, 2001; Schmitt \& Buss, 2000).

Claims that the Big Five factors are robust (Goldberg, 1993) and basic (Costa \& McCrae, 1992) also have been queried. It is important to note that Openness to Experience has not been found in lexical analyses. In addition, both lexical and psychophysiological approaches have suggested factor structures other than the Big Five (see Boyle et al., 1995; McKenzie et al., 1997). Apparently, Costa and McCrae's initial three-dimensional (NEO) solution was derived from a cluster analysis of the Cattellian personality trait intercorrelations (cf. McKenzie, 1998, p. 479). However, cluster analysis cannot detect underlying source traits, and instead, can only reveal superficial syndrome groupings. Nevertheless, while some factoranalytically oriented personality researchers (e.g., Cattell, 1995; Comrey, 1993) have proposed additional trait dimensions, tentative support for the FFM has been provided in studies by Hofstee et al. (1992), Marusik et al., 1996; as well as by Piedmont and Chae (1997). Also there have been replications of the FFM using representative adjective samples from various languages (cf. Goldberg, 1992; McCrae \& Allik, 2002; McCrae et al., 2004). 
The empirical evidence shows that Openness and Conscientiousness dimensions appear to differ from one study to another (e.g., Hofstee et al., 1992; Johnson \& Ostendorf, 1993; Stumpf, 1993). Also, several investigators, despite having factor analyzed FFM markers, have not been able to reproduce the popular Big Five structure (e.g., Church \& Burke, 1994; Livneh \& Livneh, 1989; Schmit \& Ryan, 1993). Even though these studies have sometimes used non-representative item samples and small sample sizes, it does appear, nevertheless, that the FFM cannot be reproduced reliably across different samples (Block, 1995, p. 200; Waller, 1995).

The study by McKenzie et al. (1997) did not support the FFM dimensions labelled Agreeableness, Conscientiousness, and Openness to Experience. However, since McKenzie et al. based their analyses on Cattellian and Eysenckian measures (neither of which has good Openness to Experience markers), it not altogether surprising that their factor solution differed from that of the FFM. In fact, Eysenck (1991, p. 667) previously had suggested that these three dimensions are correlated primaries which coalesce into a single higher-stratum Psychoticism (P) factor. On the other hand, Egan et al. (2000) subjected NEO-FFI data derived from a large sample ( $\mathrm{N}=$ 1025) to both exploratory and confirmatory factor analysis, but obtained support for only three dimensions (Neuroticism, Agreeableness, and Conscientiousness). In addition, Saucier and Goldberg (2001) found that three factors emerged from a larger range of languages than did all Big Five dimensions, raising further concerns about the construct validity of the FFM. The apparent dynamic complexity of human personality structure and its developmental characteristics across the human lifspan, as highlighted via Cattellian structured personality-learning, would seem to necessitate a model other than the static Big Five approach (cf. Block, 1995; Boyle, 
1993; Cattell et al., 2002; Romney \& Bynner, 1992; Hough \& Schneider, 1996;

Schneider et al., 1996). To shed further light on this problem, the methodological strategies utilised in the derivation of the FFM are next examined in some detail.

\section{Factor Analytic Methodology: NEO-PI-R and 16PF Measures}

The issue of factor-analytic methodology is critically important in the derivation of the Big Five personality dimensions. Costa and McCrae’s (1992) NEO-PI-R factors were delineated using a “top down” approach, wherein the predetermined FFM theoretical model was "verified” by manipulating exploratory factor-analytic methods in a rather idiosyncratic, and procrustean manner (Roberts et al., 2006a,b; Saucier, 2002). However, the extraction of a restricted number of factors with orthogonal rotation has been extensively critiqued (e.g., Boyle et al., 1995; McDonald, 1985) since it often precludes simple-structure solutions (see Child, 1990). Determination of the appropriate number of factors should be based on accepted criteria such as the well-established Scree test (Cattell, 1988). Simplestructure factor solutions facilitate substantive interpretation (Gorsuch, 1988). Adequate simple structure is suggested when the \pm .10 hyperplane count (i.e., proportion of trivial $\leq .10$ factor loadings) is maximized (cf. Boyle et al., 1995, p. 421). It is noteworthy that the studies conducted by Costa and McCrae (1992) appear not to have tested the simple structure of their factor analytic solutions. Likewise, Goldberg (1992), who subsequently subjected his adjectival rating data to oblique rotation, provided no quantitative evidence on hyperplane counts (cf. Cattell, 1995, p. 207). 
When observer data is added to self-report data, the overlap among factors decreases substantially, a strategy adopted by Costa and McCrae (1992) in deriving validimax factors for the NEO-PI-R. It appears that their self-report data was weighted so as to create factors with reduced correlations (Costa \& McCrae’s preference for procrustean rotation has been queried—see Block, 1995). Thus, in constructing the NEO-PI-R instrument, it appears that Costa and McCrae's analyses, rather than being empirically data-driven, were unduly influenced, and moulded specifically to accord with the popular Big Five dimensions (Block, 1995). It is not surprising, therefore, that the NEO-PI-R facet subscales have not received universal support (e.g., Glisky et al., 1991; Goldberg, 1993; Hahn \& Comrey, 1994; Tellegen, 1993; Zuckerman et al., 1993). Interestingly, oblique simple structure rotations of adjectival ratings in large samples have led to a new method for representing the FFM structure called the AB5C (Hofstee, 1994).

Costa and McCrae maintained that their observed factor intercorrelations resulted from correlated method error related to self-report data. However, there is little reason to expect, a priori, that the Big Five factors necessarily should be orthogonal. Furthermore, McCrae et al. (1996) argued that confirmatory factor analysis is too restrictive (see Mulaik, 1988; Vassend \& Skrondal, 1997, for a discussion of some of these issues). For example, McCrae and Allik (2002) pointed to a number of confirmatory factor-analytic studies that had been undertaken cross-culturally with mixed outcomes.

Other factor-analytically derived models of personality structure have also appeared, such as the second-stratum 16PF factors (Boyle, 1989; Boyle \& Smári, 2002; Boyle 
et al., 2001; Cattell \& Nichols, 1972; Gorsuch \& Cattell, 1967; Krug \& Johns, 1986), Hogan’s six personality factors (e.g., Hogan et al., 1996), the eight personality trait factors which Comrey (1993) reported, and the three broad, higherstratum factors elucidated by Eysenck (e.g., 1994)--(also see Byravan \& Ramanaiah, 1996; H.E.P. Cattell, 1995; McKenzie et al., 1997; Ormerod et al., 1995; Russell \& Karol, 1994). However, at least the first two dimensions of the Big Five (Neuroticism and Extraversion) appear to have emerged from the separate factoranalytic investigations carried out by Cattell, Comrey, and Eysenck (see Boyle, 1989).

Krug and Johns (1986) carried out a large-scale scale factoring of the 16PF and reported at least five second-stratum personality factors labelled Extraversion, Anxiety/Neuroticism, Tough Poise, Independence, and Control, plus an intelligence factor (cf. Smith, 1988). Krug and Johns based their large-scale factor analyses on the intercorrelations of Cattell's 16PF primary trait factors; they utilized simple structure factor-analytic procedures; and they checked (cross-validated) the validity of their factor-pattern solutions across separate large samples of 9222 males and 8159 females, providing strong evidence of the robustness of their factor solutions.

Nonetheless, Cattell (1995) in his position statement (The fallacy of five factors in the personality sphere) had been critical of the Krug and Johns (1986) study, claiming that they had extracted an insufficient number of second-stratum factors. Even so, the large-scale factor analysis of $16 \mathrm{PF}$ data, conducted by Krug and Johns on a combined sample of 17,381 participants, yielded a \pm .10 hyperplane count of 71\%. In contrast, Costa and McCrae’s (1992) FFM solution resulted in a \pm .10 
hyperplane count of only 31\%, suggesting that their factor solution failed to satisfy simple-structure criteria (cf. Deary, 1996, p. 992). In addition to the Extraversion and Neuroticism dimensions, Zuckerman et al. $(1993,2002)$ had also identified traits of aggression-hostility and impulsive sensation-seeking, providing yet further evidence of the limitations of the popular FFM. Clearly, the five-factor ZuckermanKuhlman Personality Questionnaire (ZKPQ) in its incorporation of biological, comparative, experimental, and trait approaches, is more sophisticated than the popular, but rather descriptive Big Five model which serves as the basis for the NEO-PI-R and NEO-FFI instruments. As Zuckerman (1991, p. 17) pointed out, the popularity of the FFM over recent years probably reflects a compromise between the minimalist three Eysenckian typological factors (e.g., Eysenck, 1994, 1997) and the far more numerous Cattellian 16PF primary factors (e.g., Cattell \& Cattell, 1995; H. E. P. Cattell, 1993, 1995, 1996a,b). Nevertheless, the predictive validity of a smaller number of higher-order factors is necessarily reduced as compared with measurement based on primary factors (Boyle et al., 1995; Cattell, 1995, p. 208; Mershon \& Gorsuch, 1988).

Rossier et al. (2004) asserted that the NEO-PI-R is more reliable than the 16PF, but as Boyle (1991) has pointed out, high item homogeneity (as measured via Cronbach alpha coefficients) may also reflect item redundancy and narrow measurement of a construct. Indeed, the Cattellian psychometric instruments have been constructed specifically to minimize item redundancy and to increase their breadth of measurement (e.g., see Cattell, 1992). As Boyle (1991) argued, moderate rather than maximum item homogeneity is psychometrically desirable. Since Rossier et al. did not report any test-retest consistency data, their conclusions about the reliability 
of the respective instruments evidently were misguided. However, putting aside such technical psychometric issues, some applications of the popular FFM are now considered, including applications within clinical and occupational contexts.

\section{The FFM and Abnormal Personality Structure}

Several studies have attempted to locate abnormal personality traits within the FFM factor space (see O’Connor \& Dyce, 2001). While the FFM has been shown to exhibit correlations with Axis II clinical constructs (e.g., Costa \& Widiger, 2002; Widiger et al., 2002), in practice, such correlations are typically observed even between quite unrelated psychometric measures, and are of little psychological importance, being attributable largely to overlapping media of measurement variance (e.g., intercorrelations between unrelated self-report scales).. Similarly, Quirk et al. (2003) examined the incremental validity of the NEO-PI-R in the prediction of Axis I and II disorders, and found that the instrument accounted for some additional diagnostic variance over and above that explained by the MMPI-2 inventory. However, such “incremental validity” may well have resulted primarily from contamination due to method variance.

Based on previous research suggesting a link between procrastination and lack of consideration for others, Lay et al. (1998) developed self-report scales to assess procrastination and the FFM dimension (Conscientiousness) in school children. They found the expected negative relationship between the two constructs. In a study of Dutch university students, Schouwenburg and Lay (1995) used the NEOPI-R to assess Conscientiousness which was also found to be inversely related to procrastinatory behaviour as suggested by self-descriptive adjectives. In contrast, 
perfectionism was correlated positively with Conscientiouness (Hill et al., 1997). When perfectionism was self-oriented, it was also positively associated with the FFM Agreeableness dimension, but when perfectionism was expected of others, it was negatively associated with Agreeableness. Moral reasoning has been shown to be related not to the FFM dimension (Conscientiousness) but to the FFM Openness to Experience-Intellectance dimension (Dollinger \& LaMartina, 1998)--(openness to values and feelings, respectively). Emotional intelligence was also found to relate more to the FFM Openness to Experience-Intellectance dimension than to the other four FFM dimensions (Schutte et al., 1998).

The studies reviewed here suggest some applicability of the FFM in the multifactorial classification of abnormal personality traits. One problem is the possible oversimplification of some of the FFM traits. For example, it has been argued that Openness to Experience-Intellectance embodies at least three different features, namely, absorption, intellectance, and liberalism (Glisky \& Kihlstrom, 1993), while Conscientiousness has been disaggregated into six facets (Schouwenberg \& Lay, 1995). Trull and Widiger developed a structured interview (SIFFM) to assess personality disorders using the NEO-PI-R as a guiding principle (see Trull et al., 1998).

Schroeder et al. (1992) found a general convergence of various measures of personality disorders with four of the FFM dimensions. Neuroticism was most related, while Openness to Experience-Intellectance was least related to personality disorders. Since there are various tried and tested tools for assessing Neuroticism, the incremental validity of the FFM in clinical diagnosis needs to be determined. 
Also, the behavioural aspects of personality disorders are not sufficiently accessed by the FFM (Schroeder et al.). A review of several studies of personality disorder symptomatology found that number of symptoms correlated with scores on FFM measures (Duijsens \& Diekstra, 1996). The evidence suggests that the FFM does explain substantial parts of the variance in abnormal personality dimensions (e.g., Bagby et al., 1999, replicated the five-factor NEO-PR-R structure in a sample of psychiatric patients), although it seems evident that additional trait dimensions are required. Furthermore, as would be expected, there is considerable overlap between FFM measures and Minnesota Multiphasic Personality Inventory (MMPI) scales (Costa \& Widiger, 2002). In addition, there are empirical links between FFM measures and DSM-IV Axis I disorders, such as the link between neuroticism and other FFM dimensions and anxiety disorders (Trull et al., 1998).

The idea of differentiating various DSM-IV defined personality disorders in terms of the FFM was discussed by Widiger et al. (2002), who reported, for example, that borderline personality disorder correlated highly with the Neuroticism dimension; that schizotypal personality disorder correlated highly with Introversion; and that histrionic personality correlated with Extraversion. In addition, Ignjatovic and Svrakic (2003) investigated the utility of both the FFM and the Cloninger sevenfactor model (Cloninger et al., 1999) in relation to Axis I and II mental disorders (depression, psychoses, anxiety, and personality disorder) among Yugoslav psychiatric patients. Their empirical findings supported the applicability of both psychometric models. However, since the FFM does not provide specific coverage of the abnormal trait domain, as measured for example in the MMPI, the Clinical Analysis Questionnaire (CAQ), or the Personality Assessment Inventory (PAI), this 
leaves the FFM quite a way from the clinical objective of differential diagnosis of personality disorders and Axis I mental disorders (Waller, 1995), and highlights the need to consider abnormal personality trait dimensions, in addition to normal trait dimensions alone.

Thus, despite having some utility in assessing personality disorders (Costa \& Widiger, 2002; Soldz et al., 1993), the FFM does not appear to be directly helpful in psychiatric diagnosis (Clark, 1993; Waller, 1995), since it relates primarily to normal personality structure, rather than to the psychopathological trait domain. Normal personality trait dimensions may be useful in clinical applications in ways other than assisting diagnosis. For example, normal traits might capture important heterogeneity that exists within diagnostic categories. As shown in Table 1, the FFM does not appear to provide adequate coverage of the major psychoticism traits. Still, it would seem advantageous to consider simultaneously both specific and broad personality traits in evaluating clinical psychotherapeutic outcomes (e,g., see Cattell, 1987).

Parenthetically, studies have also emerged relating the FFM to somatic health. In one study of more than 1000 undergraduate students (Lemos-Giraldez \& FidalgoAliste, 1997), Conscientiousness and Agreeableness were found to be predictive of smoking, drinking alcohol, exercise, diet, and stress. Courneya and Hellsten (1998) reported that particular motives, barriers, and preferences involved in exercise behaviour related to the FFM in the expected direction, with Neuroticism and lack of Conscientiousness predicting exercise barriers. This line of investigation can be 
extended to shed light on health behaviour change which has become the subject of much interest in health psychology.

\section{Use of FFM in Personnel Selection}

In recent years, the FFM has attracted considerable attention in employee selection (cf. Noty, 1986). Major contributing influences have been influential meta-analytic studies; adoption of a framework for categorising trait measures (Fisher \& Boyle, 1997); and economic and labour market changes (Mount \& Barrick, 1995). For example, Hurtz and Donovan (2000) conducted a meta-analysis of scales designed s to measure FFM constructs. Their findings (p. 875) supported the earlier work of Barrick et al. (2001), and Mount and Barrick (1995), that Conscientiousness exhibited the highest validity of the FFM dimensions in relation to predicting job performance. As for Conscientiousness, Hurtz and Donovan (pp. 875-876) concluded that the validity estimates reported by Salgado (1997) may have been overestimates. The actual predictive variance accounted for was only around $4 \%$, raising doubt as to the utility of the FFM measures in making valid predictions of occupational performance.

While the FFM has remained popular, it is evident that additional broad dimensions are needed (Hogan \& Roberts, 1996). For example, Hough (1992) added locus of control, and masculinity to the list of constructs needed to predict occupational performance. Ozer and Reise (1994) pointed out that the FFM does not include a dimension relating to self-control, despite its importance in work environments. Nevertheless, use of the FFM was supported by Ones and Viswesvaran (1996), arguing that occupational performance criteria are broad constructs. However, 
reliance on only five factors necessarily restricts predictive validity (see Hogan et al., 1996; Mershon \& Gorsuch, 1988). As well, Schneider et al. (1996) acknowledged that more specific trait dimensions are more predictive of occupational performance criteria (cf. Church \& Burke, 1994; Hofstee et al., 1992). Evidently, predictive validity is enhanced when specific traits are matched to specific occupational performance criteria, and broad traits are matched to broad occupational performance criteria (Hogan \& Roberts, 1996).

\section{Conclusions}

In summary, several problems with the currently popular FFM are apparent. For example, the FFM does not provide adequate coverage of the normal personality trait domain (let alone the abnormal personality trait domain); it is unable to be replicated consistently in different samples; it is not linked to underlying physiological mechanisms or to neurochemical brain processes; it postulates heterogeneous broad traits which are too few in number to enable highly accurate predictions; it provides a static account of regularities in behaviour; and a major difficulty with the FFM is that it has no established theoretical basis. What are the underlying biochemical, neuroanatomical, neuropharmacological, and genetic substrates of the so-called Big Five dimensions? Also, it appears that FFM personality instruments fail to detect significant sex differences in personality structure (Poropat, 2002, p. 1198). Evidently, the Big Five dimensions are too broad and heterogeneous, and lack the specificity to make accurate predictions in many real-life settings. Johnson and Kreuger (2004) examined multivariate models of genetic and environmental influences on adjectives describing the Big Five 
dimensions. It was found that each domain was aetiologically complex, raising fundamental questions about the conceptual and empirical adequacy of the FFM.

It has been asserted by Costa and McCrae (e.g., 1997, 2006), that studies of personality development have shown little maturational change for the FFM dimensions in adulthood. Nevertheless, since personality structure is constantly undergoing developmental change in response to experiential learning (Cattell et al., 2002; Roberts et al., 2006a,b; Srivastava et al., 2003), it is important to recognize that adoption of more dynamic models that take into account personality-learning processes (Cattell, 1983; Cattell et al., 2002), necessarily precludes simple models of static trait dimensions such as proposed in the FFM. Instead of representing a conceptual framework for outlining the developmental and dynamic aspects of personality traits within a larger psychological structure, the FFM tends merely to provide a descriptive account of presumed regularities in behaviour, and to view personality structure as a set of static dimensional tendencies not readily influenced by social learning experience and enculturation during childhood development. Indeed, as Rothbart et al. (2000, p. 130) pointed out, “purely descriptive models of personality do not readily lend themselves to making predictions about interactions...they tend to reinforce a simple trait-based model of personality.” In conclusion, it appears that the currently popular FFM should be replaced with an expanded and altogether more inclusive model of dynamic personality structure.

Put Table 1 about here 


\section{References}

Allport, G. W., \& Odbert, H. S. (1936). Trait names: A psycho-lexical study. Psychological Monographs, 47 (211).

Aluja, A., Garcia, O., \& Garcia, L. F. (2004) Replicability of the three, four and five Zuckerman’s personality super-factors: Exploratory and confirmatory factor analysis of the EPQ-RS, ZKPQ and NEO-PI-R. Personality and Individual Differences, 36, 1093-1108.

Angleitner, A., \& Ostendorf, F. (1994). Temperament and the Big Five factors of personality. In C. F. Halverson, Jr., G. A. Kohnstamm, \& R. P. Martin (Eds.), The developing structure of temperament and personality from infancy to adulthood (pp. 69-90). Hillsdale, NJ: Erlbaum.

Ashton, M. C., Lee, K., Perugini, M., Szarota, P., de Vries, R. E., Di Blas, L., Boies, K.; \& De Raad, B. (2004). A six-factor structure of personality-descriptive adjectives: Solutions from psycholexical studies in seven languages. Journal of Personality and Social Psychology, 86,356-366.

Bagby, R. M., Costa, P. T Jr., McCrae, R. R., Livesley, W. J., Kennedy, S. H., Levitan, R. D., Levitt, A. J., Joffe, R. T., \& Young, L. T. (1999). Replicating the five factor model of personality in a psychiatric sample. Personality and Individual Differences. 27, 1135-1139.

Barbaranelli, C., \& Caprara, G. V. (2000). Measuring the Big Five in self-report and other ratings: A multitrait-multimethod study. European Journal of Psychological Assessment, 16, 31-43.

Barrick, M. R., Mount, M. K., \& Judge, T. A. (2001). Personality and performance at the beginning of the new millennium: What do we know and where do we go next? Personality and Performance, 9, 9-30. 
Benet-Martínez, V., \& John, O. P. (1998). ‘Los Cinco Grandes’ across cultures and ethnic groups: Multitrait-Multimethod analyses of the Big Five in Spanish and English. Journal of Personality and Social Psychology, 75, 729-750.

Block, J. (1995). A contrarian view of the five-factor approach to personality description. Psychological Bulletin, 117, 187-229.

Block, J. (2001). Millenial contrarianism: The five factor approach to personality description 5 years later. Journal of Research in Personality, 35, 98-107.

Boyle, G. J. (1989). Re-examination of the major personality-type factors in the Cattell, Comrey, and Eysenck scales: Were the factor solutions by Noller et al. optimal? Personality and Individual Differences, 10, 1289-1299.

Boyle, G. J. (1991). Does item homogeneity indicate internal consistency or item redundancy in psychometric scales? Personality and Individual Differences, 12, 291-294.

Boyle, G. J. (1993). [Review of D. M. Romney \& J. M. Bynner (1992) “The structure of personal characteristics.”] Contemporary Psychology, 38, 1080-1081.

Boyle, G. J. (1997). Crisis in traditional personality assessment: Implications for military testing. Proceedings of the $39^{\text {th }}$ Annual Conference of the International Military Testing Association (pp. 61-64), Sydney, October 14-16.

Boyle, G. J., Ortet, G., \& Ibáñez, M. I. (2001). Evaluación de la personalidad y la inteligencia: Una perspectiva cattelliana. Universitas Tarraconensis Revista de Psicología, 23,73-92.

Boyle, G. J., \& Saklofske, D. H. (2004). (Eds.), Sage benchmarks in psychology: The psychology of individual differences (4 Vols.). London, UK: Sage. 
Boyle, G. J., \& Smári, J. (1997). De fem stora och personlighetspsykologins matningsproblem (Big Five and the problem of measurement in the psychology of personality). Nordisk Psykologi, 49, 12-21.

Boyle, G. J., \& Smári, J. (1998). Statiska femfaktorpersonlighets-modeller-Svar till Engvik (Static five-factor models of personality: A reply to Engvik). Nordisk Psykologi, 50, 216-222.

Boyle, G. J., \& Smári, J. (2002). Vers une simplification du modèle cattellien de la personnalité. Bulletin de Psychologie, 55, 635-643.

Boyle, G. J., Stankov, L., \& Cattell, R. B. (1995). Measurement and statistical models in the study of personality and intelligence. In D. H. Saklofske \& M. Zeidner (Eds.), International handbook of personality and intelligence (pp. 417-446). New York: Plenum.

Buss, D. M. (1996). Social adaptation and five major factors of personality. In J. S. Wiggins (Ed.), The five-factor model of personality: Theoretical perspectives (pp. 180-207). New York: Guilford.

Byravan, A., \& Ramanaiah, N. V. (1996). Study of the structure of the 16PF fifth edition from the perspective of the five-factor model - Reply. Psychological Reports, 79, 123-126.

Caprara, G. V., Barbaranelli, C., Hahan, R., \& Comrey, A. L. (2001). Factor analyses of the NEO-PI-R inventory and the Comrey personality scales in Italy and the United States. Personality and Individual Differences, 30, 217-228.

Caprara, G. V., Barbaranelli, C., \& Borgogni, L. (1994). BFO: Big Five Observer Manual. Firenze, Italy: Organizzazioni Speciali.

Cattell, H. E. P. (1993)."The structure of phenotypic personality traits": Comment. American Psychologist, 48, 1302-1303. 
Cattell, H. E. P. (1995). Some comments on a factor analysis of the 16PF and NEO Personality Inventory - Revised. Psychological Reports, 77, 1307-1311.

Cattell, H. E. P. (1996a). The original big five: An historical perspective. Revue Européenne de Psychologie Appliquée, 46, 5-14.

Cattell, H. E. P. (1996b). The original Big-Five personality factor structure. Bollettino di Psicologia Applicata, 219, 15-29.

Cattell, R. B. (1983). Structured personality-learning theory: A wholistic multivariate research approach. New York: Praeger.

Cattell, R. B. (1986). The 16PF personality structure and Dr. Eysenck. Journal of Social Behavior and Personality, 1, 153- 160.

Cattell, R. B. (1987). Psychotherapy by structured learning theory. New York: Springer.

Cattell, R. B. (1988). The meaning and strategic use of factor analysis. In J. R. Nesselroade \& R. B. Cattell (Eds.), Handbook of multivariate experimental psychology (2nd ed.). New York: Plenum.

Cattell, R. B. (1992). Human motivation objectively, experimentally analysed. British Journal of Medical Psychology, 65, 237-243.

Cattell, R. B. (1995). The fallacy of five factors in the personality sphere. Psychologist, 8, 207-208.

Cattell , R. B. (1996). Personality and structured learning. European Review of Applied Psychology, 46 73-75.

Cattell, R. B., Boyle, G. J., \& Chant, D. (2002). Enriched behavioral prediction equation and its impact on structured learning and the dynamic calculus. Psychological Review, 109, 202-205. 
Cattell, R. B, \& Cattell, H. E. P. (1995). Personality structure and the new fifth edition of the 16PF. Educational and Psychological Measurement, 55, 926-937.

Cattell, R. B., \& Nichols, K. E. (1972). An improved definition, from 10 researches, of second order personality factors in Q-data (with cross-cultural checks). Journal of Social Psychology, 86, 187-203.

Child, D. (1990). The essentials of factor analysis ( $2^{\text {nd }}$ ed.). London, UK: Cassell.

Church, A. T., \& Burke, P. J. (1994). Exploratory and confirmatory tests of the Big Five and Tellegen's three- and four-dimensional models. Journal of Personality and Social Psychology, 66, 93-114.

Clark, L. A. (1993). Personality disorder diagnosis: Limitations of the five-factor model. Psychological Inquiry, 4, 100-104.

Cloninger, C. R., Svrakic, D. M., Bayon, C., \& Przybeck, T. R. (1999). Measurement of psychopathology as variants of personality. In C. R. Cloninger (Ed.), Personality and psychopathology (pp. 33-65). Washington, DC: American Psychiatric Association.

Comrey, A. L. (1993). Revised manual and handbook of interpretation for the Comrey Personality Scales. San Diego: Educational and Industrial Testing Service.

Costa, P. T., Jr., \& McCrae, R. R. (1992). Revised NEO Personality Inventory and NEO Five-Factor Inventory: Professional manual. Odessa, FL: Psychological Assessment Resources.

Costa, P. T., Jr., \& McCrae, R. R. (1997). Longitudinal stability of adult personality. In R. Hogan, J. A. Johnson, \& S. R. Briggs (Eds.), Handbook of personality psychology (pp. 269-290). Orlando, FL: Academic. 
Costa, P. T., Jr., \& McCrae, R. R. (2006). Age changes in personality and their origins: Comment on Roberts, Walton, and Viechtbauer (2006). Psychological Bulletin, 132, 26-28.

Costa, P. T., Jr., \& Widiger, T. A. (2002). (Eds), Personality disorders and the fivefactor model of personality $\left(2^{\text {nd }} \mathrm{ed}\right)$. Washington, DC: American Psychological Association.

Courneya, K. S., \& Hellsten, L. A. (1998). Personality correlates of exercise behaviour, motives, barriers and preferences: An application of the five-factor model. Personality and Individual Differences, 24, 625-633.

Deary, I. J. (1996). A (latent) Big Five personality model in 1915? A reanalysis of Webb’s data. Journal of Personality and Social Psychology, 71, 992-1005.

Deary, I. J., \& Matthews, G. (1993). Personality traits are alive and well. Psychologist, 6, 299-311.

De Raad, B., \& Perugini, M. (2002). Big Five Assessment. Seattle, WA: Hogrefe \& Huber.

Dollinger, S. J., \& LaMartina, A. K. (1998). A note on moral reasoning and the fivefactor model. Journal of Social Behavior and Personality, 13, 349-358.

Duijsens, I. J., \& Diekstra, R. F. W. (1996). DSM-III-R and ICD-10 personality disorders and their relationship with the Big Five dimensions of personality. Personality and Individual Differences, 21, 119-133.

Egan, V., Deary, I., \& Austin, E. (2000). The NEO-FFI: emerging British norms and an item level analysis suggest $\mathrm{N}, \mathrm{A}$ and $\mathrm{C}$ are more reliable than $\mathrm{O}$ and E. Personality and Individual Differences, 29, 907-920.

Egger, J. I. M., De Mey, H. R. A., Derksen, J. J. L., \& van der Staak, C. P. F. (2003). Cross-cultural replication of the Five Factor Model and comparison of the NEO-PI- 
R and MMPI-2 PSY-5 scales in a Dutch psychiatric sample. Psychological Assessment, 15, 81-88.

Eysenck, H. J. (1991). Dimensions of personality: 16, 5, 3?: Criteria for a taxonomic paradigm. Personality and Individual Differences, 12, 773-790.

Eysenck, H. J. (1992). Four ways five factors are not basic. Personality and Individual Differences, 13, 667-673.

Eysenck, H. J. (1993). Comment on Goldberg. American Psychologist, 48, 1299-1300. Eysenck, H. J. (1994). The Big Five or giant three: Criteria for a paradigm. In C. F. Halverson, G. A. Kohnstamm, \& R. P. Martin (Eds.), The developing structure of temperament and personality from infancy to adulthood (pp. 37-51). Hillsdale, NJ: Erlbaum.

Eysenck, H. J. (1997). Personality and experimental psychology: The unification of psychology and the possibility of a paradigm. Journal of Personality and Social Psychology, 73, 1224-1237.

Fisher, C. D., \& Boyle, G. J. (1997). Personality and employee selection: Credibility regained. Asia Pacific Journal of Human Resources, 35, 2, 26-40.

Fraley, R. C., \& Roberts, B. W. (2005). Patterns of continuity: A dynamic model for conceptualizing the stability of individual differences in psychological constructs across the life course. Psychological Review, 112, 60-74.

Glisky, M. L., \& Kihlstrom, J. F. (1993). Hypnotizability and facets of openness. International Journal of Clinical and Experimental Hypnosis, 41, 112-123.

Glisky, M. L., Tataryn, D. J., Tobias, B. A., Kihlstrom, J. F., \& McConkey, K. M. (1991). Absorption, openness to experience, and hypnotizability. Journal of Personality and Social Psychology, 60, 263-272. 
Goldberg, L. R. (1992). The development of markers for the Big Five factor structure. Psychological Assessment, 4, 26-42.

Goldberg, L. R. (1993). The structure of phenotypic personality traits. American Psychologist, 48, 26-34.

Gorsuch, R. L. (1988). Exploratory factor analysis. In J. R. Nesselroade \& R. B. Cattell (Eds.), Handbook of multivariate experimental psychology (2nd ed.). New York: Plenum.

Gorsuch, R. L., \& Cattell, R. B. (1967). Second stratum personality factors defined in the questionnaire realm by the 16PF. Multivariate Behavioral Research, 2, 211-224.

Gosling, S. D., Rentfrow, P. J., \& Swann, W. B., Jr. (2003). A very brief measure of the big-five personality domains. Journal of Research in Personality, 37, 504-528.

Haggbloom, S. J., Warnick, R., Warnick, J. E., Jones, V. K., Yarbrough, G. L., Russell, T. M., Borecky, C. M., McGahhey, R., Powell III, J. L., Beavers, J., \& Monte, E. (2002). The 100 most eminent psychologists of the $20^{\text {th }}$ century. Review of General Psychology, 6, 139-152.

Hahn, R., \& Comrey, A. L. (1994). Factor analysis of the NEO-PI and the Comrey Personality Scales. Psychological Reports, 75, 355-365.

Hofstee, W. K. B. (1994). The abridged Big Five circumplex (AB5C) model of trait structure: Heymans’ cube, Kiesler’s circle and Peabody and Goldberg’s double cone model. European Review of Applied Psychology, 44, 27-33.

Hofstee, W. K. B., Raad, de B., \& Goldberg, L. R. (1992). Integration of the Big Five and circumplex approaches to trait structure. Journal of Personality and Social Psychology, 63, 146-163.

Hogan, R., Hogan, J., \& Roberts, B. W. (1996). Personality measurement and employment decisions. American Psychologist, 51, 469-477. 
Hogan, J., \& Roberts, B. W. (1996). Issues and non-issues in the fidelity-bandwidth trade-off. Journal of Organizational Behavior, 17, 627-637.

Hough, L. M. (1992). The Big Five personality variables--construct confusion: Description versus prediction. Human Performance, 5, 139-155.

Hough, L. M., \& Schneider, R. J. (1996). Personality traits, taxonomies, and applications in organizations. In K. R, Murphy (Ed.), Individual differences and behavior in organizations (pp. 31-87). San Francisco, CA: Jossey-Bass.

Hurtz, G. M., \& Donovan, J. J. (2000). Personality and job performance: The big five revisited. Journal of Applied Psychology, 85, 869-879.

Ignjatovic, T. D., \& Svrakic, D. (2003). Western personality models applied in Eastern Europe: Yugoslav data. Comprehensive Psychiatry, 44, 51-59.

Jang, K. L., Livesley, W. J., Angleitner, A., Riemann, R., \& Vernon, P. A. (2002). Genetic and environmental influences on the covariance of facets defining the domains of the five factor model of personality. Personality and Individual Differences, 33, 83-101.

John, O. P. (1990). The Big Five factor taxonomy: Dimensions of personality in the natural language and in questionnaires. In L. Pervin (Ed.), Handbook of personality theory and research (pp. 66-100). New York: Guilford.

John, O. P., \& Srivastava, S. (1999). The Big Five trait taxonomy: History, measurement, and theoretical perspectives. In L. A. Pervin \& O. P. John (Eds.), Handbook of personality: Theory and research (pp. 102-138). New York: Guilford. Johnson, J. A., \& Ostendorf, F. (1993). Clarification of the five-factor model with the abridged big five dimensional circumplex. Journal of Personality and Social Psychology, 65, 563-576. 
Johnson, W., \& Krueger, R. F. (2004). Genetic and environmental structure of adjectives describing the domains of the Big Five Model of personality: A nationwide US twin study. Journal of Research in Personality, 38, 448-472.

Krug, S. E., \& Johns, E. F. (1986). A large scale cross-validation of second-order personality structure defined by the 16PF. Psychological Reports, 59, 683-693.

Lay, C., Kovacs, A., \& Danto, D. (1998). The relation of trait procrastination to the big-five factor conscientiousness: An assessment with primary junior school children based on self-report scales. Personality and Individual Differences, 25, 187-193.

Lemos-Giraldez, S., \& Fidalgo-Aliste, A. M. (1997). Personality dispositions and health-related habits and attitudes: A cross-sectional study. European Journal of Personality, 11, 197-209.

Livneh, H., \& Livneh, C. (1989).The five-factor model of personality: Is evidence of its cross-measure validity premature? Personality and Individual Differences, 10, 75-80.

Loehlin, J. C., McCrae, R. R., Costa, P. T., Jr., \& John, O. P. (1998). Heritabilities of common and measure-specific components of the Big Five personality factors. Journal of Research in Personality, 32, 431-453.

Marusic, I., Bratko, D., \& Eterovic, H. (1996). A contribution to the cross-cultural replicability of the five-factor personality model. Review of Psychology, 3, 23-35.

Markey, C. N., Markey, P. M., \& Tinsley, B. J. (2003). Personality, puberty, and preadolescent girls’ risky behaviours: Examining the predictive value of the fivefactor model of personality. Journal of Research in Personality, 37, 405-419.

Matthews, G., Deary, I. J.; \& Whiteman, M. C. (2003). Personality traits ( ${ }^{\text {nd }}$ ed.). New York: Cambridge. 
McAdams, D. P. (1992). The five-factor model in personality: A critical appraisal. Journal of Personality, 60, 329-361.

McCrae, R. R., \& Allik, J. (2002). (Eds.), The Five-Factor model of personality across cultures. New York: Kluwer/Plenum.

McCrae, R. R., \& Costa, P. T., Jr. (1999). A five-factor theory of personality. In L. A. Pervin \& O. P. Johns (Eds.), Handbook of personality theory and research $\left(2^{\text {nd }}\right.$ ed., pp. 139-153). New York: Guilford.

McCrae, R. R., \& Costa, P. T., Jr. (2004). A contemplated revision of the NEO Five Factor Inventory. Personality and Individual Differences, 36, 587-596.

McCrae, R. R., Costa Jr., P. T., Martin, T. A., Oryol, V.E., Rukavishnikov, A. A., Senin, I. G. Hrebickova, M., \& Urbanek, T. (2004). Consensual validation of personality traits across cultures. Journal of Research in Personality, 38, 179-201.

McCrae, R. R., \& Terracciano, A. (2005). Universal features of personality traits from the observer's perspective: Data from 50 cultures. Journal of Personality and Social Psychology, 88, 547-561.

McCrae, R. R., Zonderman, A. B., Costa, P. T., Jr., Bond, M. H., \& Paunonen, S. V. (1996). Evaluating replicability of factors in the Revised NEO Personality Inventory: Confirmatory factor analysis and Procrustes rotation. Journal of Personality and Social Psychology, 70, 552-566.

McDonald, R. P. (1985). Factor analysis and related methods. Hillsadale, NJ: Erlbaum.

McKenzie, J. (1998). Fundamental flaws in the five factor model: A re-analysis of the seminal correlation matrix from which the "openness-to-experience” factor was extracted. Personality and Individual Differences, 24, 475-480. 
McKenzie, J., Tindell, G., \& French, J. (1997). The great triumvirate: Agreement between lexically and psycho-physiologically based models of personality. Personality and Individual Differences, 22, 269-277.

Mershon, B., \& Gorsuch, R. L. (1988). Number of factors in the personality sphere: Does increase in factors increase predictability of real-life criteria? Journal of Personality and Social Psychology, 55, 675-680.

Miller, J. D., Lynam, D., Zimmerman, R. S., Logan, T. K., Leukefeld, C., \& Clayton, R. (2004). The utility of the Five Factor Model in understanding risky sexual behavior. Personality and Individual Differences, 36, 1611-1626.

Mount, M. K., \& Barrick, M. R. (1995). The big five personality dimensions: Implications for research and practice in human resource management. Research in Personnel and Human Resource Management, 13, 153-200.

Mulaik, S. A. (1988). Confirmatory factor analysis. In J. R. Nesselroade \& R. B. Cattell (Eds.), Handbook of multivariate experimental psychology (2nd ed.). New York: Plenum.

Noty, C. (1986). Industrial and vocational selection. In R. B. Cattell \& R. C. Johnson (Eds.), Functional psychological testing: Principles and instruments. New York: Brunner/Mazel.

O’Connor, B. P. (2002). A quantitative review of the comprehensiveness of the fivefactor model in relation to popular personality inventories. Assessment, 9, 188-203.

O’Connor, B. P., \& Dyce, J. A. (2001). Rigid and extreme: A geometric representation of personality disorders in five-factor model space. Journal of Personality and Social Psychology, 81, 1119-1130. 
Ones, D. S., \& Viswesvaran, C. (1996). Bandwidth-fidelity dilemma in personality measurement for personnel selection. Journal of Organizational Behavior, 17, 609626.

Ormerod, M. B., McKenzie, J., \& Woods, A. (1995). Final report on research relating to the concept of five separate dimensions of personality--or six including intelligence. Personality and Individual Differences, 18, 451-461.

Ozer, D. J., \& Reise, S. P. (1994). Personality assessment. Annual Review of Psychology, 45, 357-388.

Paunonen, S. V. (2003). Big five factors of personality and replicated predictions of behaviour. Journal of Personality and Social Psychology, 84, 411-424.

Paunonen, S. V., \& Ashton, M. C. (2001). Big five factors and facets and the prediction of behaviour. Journal of Personality and Social Psychology, 81, 524-539.

Paunonen, S. V., Ashton, M. C., \& Jackson, D. N. (2001). Nonverbal assessment of the Big Five personality factors. European Journal of Personality, 15, 3-18.

Paunonen S. V., \& Jackson, D. N. (2000). What is beyond the Big Five? Plenty! Journal of Personality, 68, 821-835.

Peabody, D., \& De Raad, B. (2002). The substantive nature of psycholexical personality factors: A comparison across languages. Journal of Personality and Social Psychology, 83, 983-997.

Piedmont, R. L., \& Chae, J. H. (1997). Cross-cultural generalizability of the five-factor model of personality: Development and validation of the NEO-PI-R for Koreans. Journal of Cross-Cultural Psychology, 28, 131-155.

Poropat, A. (2002). The relationship between atrributional style, gender and the FiveFactor Model of personality. Personality and Individual Differences, 33, 1185-1201. 
Quirk, S. W., Christiansen, N. D., Wagner, S. H., \& McNulty, J. L. (2003). On the usefulness of measures of normal personality for clinical assessment: Evidence of the incremental validity of the Revised NEO Personality Inventory. Psychological Assessment, 15, 311-325.

Roberts, B. W. (2006). Personal communication. October 21.

Roberts, B. W., Walton, K. E., \& Viechtbauer, W. (2006a). Patterns of mean-level change in personality traits across the life course: A meta-analysis of longitudinal studies. Psychological Bulletin, 132, 1-25.

Roberts, B. W., Walton, K. E., \& Viechtbauer, W. (2006b). Personality traits change in adulthood: Reply to Costa and McCrae (2006). Psychological Bulletin, 132, 29-32.

Romney, D. M., \& Bynner, J. M. (1992). The structure of personal characteristics. Westport, CT: Praeger.

Rossier, J., de Stadelhofen, F. M., \& Berthoud, S. (2004). The hierarchical structures of the NEO-PI-R and 16 PF 5. European Journal of Psychological Assessment, 20, 2738.

Rothbart, M. K., Ahadi, S. A., \& Evans, D. E. (2000). Temperament and personality: Origins and outcomes. Journal of Personality and Social Psychology, 78, 122-135.

Russell, M. T., \& Karol, D. L. (1994). The 16PF Fifth Edition Administrator's Manual. Champaign, IL: IPAT.

Salgado, J. F. (1997). The five factor model of personality and job performance in the European community. Journal of Applied Psychology, 82, 30-43.

Saucier, G. (1994). Mini-markers: A brief version of Goldberg’s unipolar Big-Five markers. Journal of Personality Assessment, 63, 506-516.

Saucier, G. (2002). Orthogonal markers for orthogonal factors: The case of the Big Five. Journal of Research in Personality, 36, 1-31. 
Saucier, G., \& Goldberg, L. R. (2001). Lexical studies of indigenous personality factors: premises, products and prospects. Journal of Personality, 69, 847-879.

Saulsman, L. M., \& Page, A. C. (2004). The five-factor model and personality disorder empirical literature: A meta-analytic review. Clinical Psychology Review, 23, 10551085.

Scandell, D. J. (2000). Development and initial validation scales for the NEO-Five Factor Inventory. Personality and Individual Differences, 29, 1153-1162.

Schmitt, D. P., \& Buss, D. M. (2000). Sexual dimensions of person description: Beyond or subsumed by the big five? Journal of Research in Personality, 34, 141177.

Schmit, M. J., \& Ryan, A. M. (1993). The big five in personnel selection: Factor structure in applicant and nonapplicant populations. Journal of Applied Psychology, 78, 966-974.

Schneider, R. J., Hough, L. M., \& Dunnette, M. D. (1996). Broadsided by broad traits: How to sink science in five dimensions or less. Journal of Organizational Behavior, 17, 639-655.

Scholte, R. H. J., \& De Bruyn, E. E. J. (2004). Comparison of the giant three and the big five in early adolescents. Personality and Individual Differences, 36, 1353-1371.

Schouwenberg, H. C., \& Lay, C. H. (1995). Trait procrastination and the Big Five factors of personality. Personality and Individual Differences, 18, 481-490.

Schroeder, M. L., Wormworth, J. A., \& Livesley, W. J. (1992). Dimensions of personality disorder and their relationships to the Big Five dimensions of personality. Psychological Assessment, 4, 47-53. 
Schutte, N. S., Malouff, J. M., Hall, L. E., Haggerty, D. J., Cooper, J. T., Golden, C. J., \& Dornheim, L. (1998). Development and validation of a measure of emotional intelligence. Personality and Individual Differences, 25, 167-177.

Shafer, A. B. (2001). The big five and sexuality trait terms as predictors of relationships and sex. Journal of Research in Personality, 35, 313-338.

Smith, B. D. (1988). Personality: Multivariate systems theory and research. In J. R. Nesselroade \& R. B. Cattell (Eds.), Handbook of multivariate experimental psychology (2 ${ }^{\text {nd }}$ ed.). New York: Plenum.

Soldz, S., Budman, S., Demby, A., \& Merry, J. (1993). Representation of personality disorders in circumplex and five-factor space: Explorations with a clinical sample. Psychological Assessment, 5, 41-52.

Soldz, S., \& Vaillant, G. E. (1999). The Big Five personality traits and the life course: A 45-year longitudinal study. Journal of Research in Personality, 33, 208-232.

Spinath, B., Spinath, F. M., Riemann, R., \& Angleitner, A. (2003). Implicit theories about personality and intelligence and their relationship to actual personality and intelligence. Personality and Individual Differences, 35, 939-951.

Srivastava, S., John, O. P., Gosling, S., \& Potter, J. (2003). Development of personality in early and middle adulthood: Set like plaster or persistent change? Journal of Personality and Social Psychology, 84, 1041-1053.

Stumpf, H. (1993). The factor structure of the Personality Research Form: A crossnational evaluation. Journal of Personality, 61, 27-48.

Tellegen, A. (1993). Folk concepts and psychological concepts of personality and personality disorder. Psychological Inquiry, 4, 122-130.

Terracciano, A., Costa, P. T Jr., McCrae, R. R. (2006). Personality plasticity after age 30. Personality and Social Psychology Bulletin, 32, 999-1009. 
Toomela, A. (2003). Relationships between personality structure, structure of word meaning, and cognitive ability: A study of cultural mechanisms of personality. Journal of Personality and Social Psychology, 85, 723-735.

Trull, T. J., Widiger, T. A., Useda, J. D., Holcomb, J., Doan, B-T., Axelrod, S. R., Stern, B. L., \& Gershuny, B. S. (1998). A structured interview for the assessment of the Five-Factor Model of Personality. Psychological Assessment, 10, 229-240.

Vassend, O., \& Skrondal, A. (1997). Validation of the NEO Personality Inventory and the five-factor model. Can findings from exploratory and confirmatory factor analysis be reconciled? European Journal of Personality, 11, 147-166.

Waller, N. G. (1995). Evaluating the structure of personality. In R. Cloninger (Ed.), Personality and psychopathology. Washington, DC: American Psychiatric Association.

Widiger, T. A., Costa, P. T., Jr., \& McCrae, R. R. (2002). A proposal for Axis II: Diagnosing personality disorders using the five-factor model. In P. T. Costa, Jr.\& T. A. Widiger (Eds), Personality disorders and the five-factor model of personality ( $2^{\text {nd }}$ ed.) (pp. 431-456). Washington, DC: American Psychological Association. Zuckerman, M. (1991). Psychobiology of personality. New York: Cambridge. Zuckerman, M. (2002). Zuckerman-Kuhlman Personality Questionnaire (ZKPQ): An alternative five-factorial model. In B. De Raad, \& M. Perugini (Eds.), Big five assessment (pp. 376-392). Ashland, OH: Hogrefe \& Huber.

Zuckerman M., Kuhlman, D. M., Joireman, J., Teta, P., \& Kraft, M. (1993). A comparison of three structural models for personality: The big three, the big five, and the alternative five. Journal of Personality and Social Psychology, 65, 757-768. 
Table 1

Comparison of Major Personality Trait Models

\begin{tabular}{|c|c|c|c|c|c|c|c|}
\hline Big Five & Eysenck & $\underline{16 P F 5}$ & $\underline{\mathrm{CAQ}}$ & $\underline{\text { Brand }}$ & $\underline{\text { Hogan }}$ & Comrey & $\underline{\text { Hough }}$ \\
\hline Extraversion & $\begin{array}{l}\text { Extraver } \\
\text { sion }\end{array}$ & $\begin{array}{l}\text { Extraversi } \\
\text { on }\end{array}$ & $\begin{array}{l}\text { Extraversi } \\
\text { on }\end{array}$ & $\begin{array}{l}\text { Neuroticis } \\
\mathrm{m}\end{array}$ & $\begin{array}{l}\text { Sociabilit } \\
\mathrm{y}\end{array}$ & Extraversion & Affiliation \\
\hline $\begin{array}{l}\text { Emotional } \\
\text { Stability }\end{array}$ & $\begin{array}{l}\text { Neurotici } \\
\text { sm }\end{array}$ & Anxiety & Anxiety & Energy & $\begin{array}{l}\text { Adjustme } \\
\text { nt }\end{array}$ & Neuroticism & Adjustment \\
\hline $\begin{array}{l}\text { Conscientiou } \\
\text { sness }\end{array}$ & & $\begin{array}{l}\text { Superego/ } \\
\text { Control }\end{array}$ & $\begin{array}{l}\text { Superego/ } \\
\text { Control }\end{array}$ & $\begin{array}{l}\text { Conscienti } \\
\text { ousness }\end{array}$ & Prudence & Orderliness & $\begin{array}{l}\text { Dependabil } \\
\text { ity }\end{array}$ \\
\hline $\begin{array}{l}\text { Agreeablenes } \\
\mathrm{s}\end{array}$ & & $\begin{array}{l}\text { Independ } \\
\text { ence }\end{array}$ & $\begin{array}{l}\text { Independ } \\
\text { ence }\end{array}$ & Will & $\begin{array}{l}\text { Likeabilit } \\
\text { y }\end{array}$ & Trust & $\begin{array}{l}\text { Agreeablen } \\
\text { ess }\end{array}$ \\
\hline \multirow{7}{*}{$\begin{array}{l}\text { Openness to } \\
\text { Experience } \\
\text { (Intellectance } \\
\text { / Culture) }\end{array}$} & & $\begin{array}{l}\text { Intelligen } \\
\text { ce }\end{array}$ & $\begin{array}{l}\text { Intelligen } \\
\text { ce }\end{array}$ & Intelligence & $\begin{array}{l}\text { Intellecta } \\
\text { nce }\end{array}$ & & $\begin{array}{l}\text { Intellectanc } \\
\text { e }\end{array}$ \\
\hline & & $\begin{array}{l}\text { Tough } \\
\text { Poise }\end{array}$ & $\begin{array}{l}\text { Tough } \\
\text { Poise }\end{array}$ & Affection & Ambition & Masculinity & $\begin{array}{l}\text { Rugged } \\
\text { Individuali } \\
\text { sm } \\
\text { Masculinit } \\
\text { y }\end{array}$ \\
\hline & $\begin{array}{l}\text { Psychoti } \\
\text { cism }\end{array}$ & & $\begin{array}{l}\text { Psychotic } \\
\text { ism }\end{array}$ & & & & $\begin{array}{l}\text { Locus of } \\
\text { Control }\end{array}$ \\
\hline & & & $\begin{array}{l}\text { Socialisat } \\
\text { ion }\end{array}$ & & & $\begin{array}{l}\text { Social } \\
\text { Conformity }\end{array}$ & \\
\hline & & & $\begin{array}{l}\text { Depressio } \\
\mathrm{n}\end{array}$ & & & & \\
\hline & & & & & & Activity & \\
\hline & & & & & & Empathy & \\
\hline
\end{tabular}

